\title{
Travel Journalism: News Framing Policy of Five Super-Priority Tourism Destinations in the Contemporary Online News Media
}

\author{
Kencana Ariestyani \\ Department of Communication Science \\ Universitas Paramadina \\ Jakarta, Indonesia \\ kencana.ariestyani@paramadina.ac.id
}

\begin{abstract}
The Media has imperative role in promoting tourism by establishing a good awareness and insight to comply the needs of the travellers both domestic and international. Since the last two decades, the digital media environment has increased rapidly. In Indonesia, based on survey conducted by Nielsen Indonesia in 2017 , currently the number of digital media readers are more than print media. The improved connectivity to digital media and increased supply of online news media content has facilitated travellers in searching for information pertaining to tourism. This research focuses on how online news media frames the news of five super-priority tourism destinations in Indonesia. This study uses qualitative method combine case study on four online news media outlets in Indonesia: Kompas.com, Tribunnews.com, Liputan6.com, and Tempo.co. The in-depth interview in gathering research data were conducted with four informants who are assigned as the editor at these four online news media. The results show that these four online news media outlets had implemented news framing in creating news stories concerning to five super-priority tourism destinations. The factors in that influence in news frame-building are varies among these four online news media.
\end{abstract}

Keywords-news framing, frame-building, five super-priority tourism destinations

\section{INTRODUCTION}

The Media has imperative role in promoting tourism by establishing a good awareness and insight to comply the needs of the travellers both domestic and international. As Kumar [1] states that one of the contribution of the media in tourism is it enhance the comprehension of the travellers concerning local wisdom such as culture and environmental issues as well as culinary through news reporting to the public.

Since the last two decades, the digital media environment has increased rapidly. Nowadays, more and more people heavily rely on online media, both social media and online news outlet, as their source of news or information. The data released by Reuters Institute Digital News Report 2013-2016 shows that in a number of countries the percentage of people hinge upon smartphones for gaining access to digital news has grown fast [2]. In Indonesia, based on survey conducted by Nielsen Indonesia in 2017 , currently the number of digital media readers are more than print media. Online news reader in Indonesia has reached 50.7 million in 2017 with millennials, especially $\mathrm{Z}$ and $\mathrm{Y}$ generation, dominate this market [3]. The improved connectivity to digital media and increased supply of online news media content has facilitated travellers in searching for information pertaining to tourism. Not to mention, in this era of industry 4.0 travellers can look, book, and purchase almost all of tourism products which can be done all at once through smartphone. In this circumtances, travel journalism of online news media has also crucial role in elevating the promotion and spreading the information related to the tourism destinations in order to augment better understanding of travellers prior to make decission.

This research focuses on how online news media frames the news of five super-priority tourism destinations in Indonesia. The government of Indonesia has nominated five super-priority tourism destinations that will be evolved in 2020. The destinations are Labuan Bajo, Likupang, Lake Toba, Borobudur, and Mandalika. This program is expected can be an attraction as new Bali and elevate the economy level of people living in the surrounding area. So that they can have a better life. To attain that goal, the government has allocated a budget of more than IDR 9 trillion for the development of the five area. The Tourism and Creative Economy Ministry has also officially introduced those five super-priority destinations to international journalists in the ASEAN Tourism Forum which held on January 2020 [4].

Tewksbury and Riles states that journalists report information by framing the news in order to give the public ways to comprehend and imply issues and events [5]. Furthermore, they mention that frame-building is one of the central mechanism of the framing process which refers to the ways that affect the work of frames implemented by journalists. According to Tewskbury and Riles the process of frame building in the contemporary online news environment implicate several elements including: (1) organizational pressures and constraints; (2) interest group pressure; (3) newsroom routines; (4) and journalist orientations.

The news media outlets have routines that affect how news-stories are produced [8]. The latest expansion in news production, that is seem significant, is the role of people contribution in news through user generated content such as blogs. Related to this, Shoemaker and Reese state that networked public spaces affect news production in which increasing public participation through networked public 
spaces in a news production could influence who can specify problems and policies [5]. Interest group, as stated by Tewskbury and Riles, seek to have their preferred frames implemented to issues by speaking directly to journalists [5]. The elements of newsroom routines in frame-building, according to Shoemaker and Reese, are divided into three domains: audiences, organizations, and suppliers of content [5]. The next element that is central to frame-building, according to Tewksbury and Riles, is ideological orientations that is carried by journalists to the news-story.

In a newsroom, editors should be able to think of what topics that are important to their readers. Frame-building aids journalists in constructing news stories in order to fulfill the needs of audiences.

\section{RESEARCH METHOD}

This study uses qualitative method combine case study on four online news media outlets in Indonesia: Kompas.com, Tribunnews.com, Liputan6.com, and Tempo.co. Case studies are a scheme of examination in which the researchers delves into the event, activity, or one or more individuals as stated by Creswell [6]. The detailed data of the research collected by using a variety of procedures.

In this research, the in-depth interview in gathering research data were conducted with four informants: Ni Luh Made Pertiwi as the Travel Editor of Kompas.com, Kurnia Yustiana as the Travel Editor of Tribunnews.com, Asnida Riani as the Lifestyle Editor of Liputan6.com, and Rini Kustiani as the Lifestyle Editor of Tempo.co. The Travel rubric both in the newsroom of Liputan6.com dan Tempo.co are managed by Lifestyle Editor. This in-depth interview is about news framing implementation in reporting news of five super-priority tourism destinations. The in-depth interviews with all of the informants were organized by phone due to the tight schedule of the informants. So, they were not able to meet in person with researcher.

To enrich and sharpen the data, researcher also observed the news story pieces about five super-priority tourism destinations performed by the editors of Kompas.com, Tribunnews.com, Liputan6.com, and Tempo.co. All the gathered data analyzed by using three steps: data reduction, data display, and conclusion drawing [7].

The aim of this research is to explore the factors that affect frame-building in implementing news framing when journalists crafting news-stories on five super-priority tourism destinations. Furthermore, it is also explore the reasons in selecting theme on the five destinations.

\section{RESUlt AND DisCUSSION}

This study reveals that news framing were applied in the contemporary online news media pertaining to five superpriority tourism destinations news. Based on the data gathered through in-depth interviews and observation, various elements affect the process of news framing that had carried out by the editors. Furthermore, results also show that Google Trend had been utilized by the editors in determining the theme and news angle on the reporting of five superpriority tourism destinations. Researcher describes four analysis in this part in which researcher portrays a comprehensive comparation of frame-building with the case of four online news media outlets.

\section{A. Kompas.com}

In general, the travel desk at Kompas.com works on all topics of travel news span from tourism policy, the trending topic of tourism, culinary, leisure, to MICE. Kompas.com, however, are less accentuating the issues regarding to five super-priority tourism destinations. The travel desk editor of Kompas.com states, "We reported the news about that but it is not an in-depth reporting." To maintain the trust of readers, the Travel Editor of Kompas.com verifies information directly to the main sources related to the issue. This news sources are including local people in the tourism destinations.

In regard to frame-building, the Travel Editor of Kompas.com stated that they utilize online Google Analytics to trace the trending issues on five super-priority tourism destinations. Based on Google Anayltics, as claimed by the Travel Editor of Kompas.com, news-stories pertaining to Komodo Island in Labuan Bajo and Lake Toba are the most sought after by readers. Thus, the news framing undertake by the editor focused on these two super-priority tourism destinations.

The journalist social responsibility has also become a consideration in frame-building the issues of super-priority tourism destinations. News-stories on Komodo Island, to take as an example, some of them is written by the Travel Editor of Kompas.com with certain messages such as providing information about ethical issues when visiting Komodo Island. "For example not to bring sand from beaches on the Komodo Island because the visitors are not allowed to do so. It happened not because people didn't know the rule. They just simply didn't realize it. We also raised issue in news-story on Komodo Island that it is impossible if tourists come to Komodo Island in large number," as asserted by Travel Editor. In this case, the travel editor of Kompas.com seeks to explain the main problem among other important issues through news-stories of Komodo Island as one of the five super-priority tourism destinations.

They also observed online news sites owned by competitors to see trending issues, particularly on those five destinations. However, they were not always worked on the same issue. "It is more as an idea for us to write something better or write a news-story with a different angle," said the Travel Editor of Kompas.com. Furthermore, another elements that affect frame-building of five destination in Kompas.com are news sources, journalist value, and advertisers. "When do news framing we seek to raise all voices, at least two news sources. So, readers don't just get one insight," as said by Travel Editor of Kompas.com. They also has specific criteria in chosing tourism experts as their sources. The Travel Editor asserted that the travel desk newsroom consider sources as an expert if they are consistently in that field for at least ten years.

As for individual value, journalist orientation is also influential in the news framing-building. The travel journalists of Kompas.com are able to uphold their own value. The newsroom in Kompas.com open for any discussion, for example things that related to ethical issues when they write news-story. 


\section{B. Tempo.co}

The priority of travel news in Tempo.co also refers to trending topics about travel matters. The Lifestyle Editor in Tempo.co heavily relies on Google Trend and social media before determining news reporting of five super-priority tourism destinations. Briefly, the news reporting of the five super-priority tourism destinations were not prioritized by them if it had not become a trending topic. "If there is one of the five super-priority destinations become trending on both platform, then we will dig it up continually," said the Lifestyle Editor of Tempo.co. Once those destinations came up as trending, they reported it in detail. "Take as an example the topic about The Kaldera Toba Nomadic Escape in Lake Toba. We wrote various thing about that including the supporting facilities for tourists, outdoor dine and interesting spots for taking picture or selfie at the site. We published news with various angles," as asserted by the Lifestyle Editor of Tempo.co.

The consideration to accentuate an issue is the news value they hold on the news pieces. They have been stressing the articles around these matters: what are the points of interest of the tourism site, and why people should visit the destinations as well as how to get there. "So, there is a magnitude in the news," as stated by the Lifestyle Editor of Tempo.co.

Compare to Kompas.com and Liputan6.com, in the meanwhile, Tempo.co were not monitored the competitors' online news sites to update issues pertaining to five superpriority destinations. Tempo.co, however, keep on updating trending issues of five destinations by monitoring Google Trend. As for other factors such as news source and journalist value, as well as advertisers had no influence on news-framing of super-priority destination.

\section{Liputan6.com}

The Travel Editor of Liputan6.com stated that their priority agenda in the newsroom is supporting The Tourism and Creative Economy Ministry (Kementerian Pariwisata dan Ekonomi Kreatif) policy since tourism is one of the sectors that has an economic impact to other aspect of life. "We are not specifically highlighting certain issues in reporting the five super-priority destinations," as stated by Travel Editor of Liputan6.com. They, however, emphasized news concerning access in which the readers could have a better understanding of how to get to the five destinations, both information about transportation and infrastructure. The travel editor of Liputan6.com said, "How far are they ready for infrastructure in these five super-priority tourism destinations? The readiness of infrastructure is important because it has an impact on how people can treat tourists."

In brief, they will refers to the practical issues such as access and transportation in travel news reporting. As for news verification, the travel journalists in Liputan6.com corroborate the information by interviewing main news sources in The Tourism and Creative Economy Ministry and other related news sources such as tourism experts, and local tourism actors in the destination.

In regards to the determination of the news framing in Liputan6.com, they had daily discussions in the newsroom. One of the factor that influence the framing of the five superpriority destinations is readers who leave a comment on the related news-story. Liputan6.com, however, has also monitor the page views of the news-stories pertaining to five superpriority destination that they had written. If the page view is less, then they dig deeper into the topic or change the angle of the news-story.

Moreover, the trending issues about five super-priority destination on social media also affects the frame-building in which Liputan6.com developed those information into new news-story. To complete all necessary data, Liputan6.com conducted interview with news-sources. But if data cannot be obtained from the interviewee, they quoted related information from the official local government website. It also can be gathered from Antara and Jawa Pos online news sites that have collaborated with Liputan6.com. The selection of news sources also influences the frame-building in which news sources should be from related agencies or they are competent and credible to give statement related to five super-priority destinations.

To update the issues of five super-priorty destinations, the Lifestyle Editor of Liputan6.com monitor the Google Trend and the competitor's online news media outlet. By doing this, they could get new insight into what issues are being popular in five super-priority destinations, then the editorial team discuss to select the most appropriate news angles that can be raised by Liputan6.com into a new newsstory.

Meanwhile, journalist orientation element does not significantly affect the framing of five super-priority destinations. News-stories were written by Liputan6.com in accordance with the facts in the field, although it may be contrary to the conscience of the journalists itself. But they will let the debate concerning the issue they had written takes place among readers in the public sphere.

\section{Tribunnews.com}

In contrast, the editorial policy of travel news in Tribunnews.com focused only on tourism destinations and culinary recommendation topics for readers. Both of the topics have become the priority of their daily agenda in travel news writing as asserted by the Travel Editor of Tribunnews.com. But in the matter of five super-priority tourism destinations, they reported the news based on the trending topic in Google Trend. "We rarely into the issue of super-priority destinations. But when Labuan Bajo become a trending topic, we reported tourism destinations and culinary in Labuan Bajo," said Travel Editor of Tribunnews.com.

Monitoring Google Trend to update on trending topic about five super-priority destinations had also carried on by Tribunnews.com. To make a new news-story at the same topic, they usualy just change the title and news angle. Furthermore, Tribunnews.com also observes social media such as Instagram to update what is being trend related five super-priority destinations. In regards to this five destinations, Tribunnews.com had written news-stories that focused only on Labuan Bajo in which it was the trending topic at that time.

Due to an insufficient number of the journalist and editor at travel desk in Tribunnews.com, they had not covered news in the field. Instead, Tribunnews.com gathered a few news articles which relate to the trending topic of five destinations from online news media that are members of the Tribune 
network and also from Kompas.com. Then, they combined those articles into a new news-story with a new angle. In addition, information was also obtained from press release issued by The Tourism and Creative Economy Ministry (Kemenparekraf) and Instagram contents uploaded by the Minister of The Tourism and Creative Economy Ministry, Wishnutama. To this, The news framing of the five superpriority tourist destinations was not influenced by the news sources because Tribunnews.com had never been conducted interviews with the sources.

Like other elements in frame-building, journalist orientation or value had not affected news framing of five super-priority destinations in Tribunnews.com because they did not take their own opinions in crafting news-stories. To take as an example, the editor might consider that the cost to visit Labuan Bajo is expensive, but it does not mean they end up with had not written the news about Labuan Bajo.

Journalists gather valuable information to be utilized in news story, and determine how they present the news in an enticing and apprehensible method before it is disseminated to public. Selecting the frame in the process of writing an issue or event is one of the most important things that should be done by journalists. News frame simplify the process of news-story writing for journalists and it also aid the readers comprehend the content of news [8]. One of the central mechanism of the framing process is frame-building in which it refers to the ways that affect the work of frames applied by journalists. The frame-building in the contemporary online news environment implicate several elements. Online news media had helped the government in promoting five super-priority tourism destination by publishing news related to it. Moreover, the account of five destinations could enhance the comprehension of travellers about the destinations. Even though these online news outlets emphasize the topic mostly on destinations that popular in public such as Labuan Bajo, Lake Toba, and Borobudur.

\section{CONCLUSION}

The process of frame building in the contemporary online news environment implicate several elements including organizational pressures and constraints, interest group pressure, newsroom routines, and journalist orientations. In this case, the contemporary online news media outlets had carried on news framing in different way in which not all of the elements affect the frame-building. Furthermore, what seems most consequential about five super-priority tourism destinations news is the editors of these online news media selected the destinations based on the trending topic in Google Trend. Komodo Island in Labuan Bajo and Lake Toba, as well as Borobudur were the most trending in Google Trend. So, the editors had focused in writing newsstory on these super-priority tourism destinations.

\section{ACKNOWLEDGMENT}

The researcher would like to thanks the Editors of Kompas.com, Liputan6.com, Tempo.co, and Tribunnews.com who had participated in this research as informants to disclose valuable information and data regarded to news framing as needed.

\section{REFERENCES}

[1] S.P. Kumar, Role of Media in The Promotion of Tourism Industry in India. Global Review of Research in Tourism, Hospitality and Leisure Management. Vol 1(3). Pp. 187-192, 2014

[2] R. K. Nielsen, A. Cornia, and A. Kalogeropoulos, Challenges and opportunities for news media and journalism in an increasingly digital, mobile, and social media environment. Reuters Institute for the Study of Journalism. Council of Europe report DGI(2016)18, 2016.

[3] A. Adzkia, Pembaca berita daring meningkat, tapi belum merata. 2019. Retrived from https://beritagar.id/artikel/berita/pembaca-beritadaring-meningkat-tapi-belum-merata on March 1, 2020.

[4] R. R, Mufti, Indonesia Introduces Super-priority Tourism Destinations at ASEAN Forum. 2020. Retrieved from https://www.thejakartapost.com/news/2020/01/17/indonesiaintroduces-super-priority-tourism-destinations-at-asean-forum.html

[5] D. Tewksbury, and J. M. Riles, Framing in an interactive news environment. In Doing News Framing Analysis II (Second ed). Edited by D'Angelo, P. New York: Routledge, 2018.

[6] J. W. Creswell, Research Design: Qualitative, Quantitative, and Mixed Methods Approaches (Third ed). London, England: Sage Publications, 2009.

[7] E. L. Pambayun, Qualitative Research Methodology in Communication: Konsep, Panduan, dan Aplikasi. Jakarta: Lentera Ilmu Cendekia, 2013.

[8] P. Moy, D. Tewksbury and E. M. Rinke, "Agenda-Setting, Priming, and Framing." The International Encyclopedia of Communication Theory and Philosophy. K. B. Jensen and R. T. Craig, Eds. John Wiley \& Sons, Inc, 2016, pp. 1-13. 